\title{
ANALISIS KINERJA KEUANGAN PERUSAHAAN PADA PERUSAHAAN DAERAH AIR MINUM DI KABUPATEN KUPANG
}

Oleh:

*Munawar

\begin{abstract}
Abstrak
Tujuan penelitian ini adalah untuk mengetahui penggunaan rasio keuangan sebagai salah satu alat untuk menilai kinerja keuangan berdasarkan Keputusan Menteri Keuangan Republik Indonesia Nomor: Kep-100/MBU/2002.Penelitian ini dilakukakan pada Perusahaan Daerah Air Minum Kabupaten Kupang dengan menggunakan data laporan keuangan 3 tahun yaitu tahun 2009, 2010, dan 2011. Alat analisis yang digunakan dalam penelitian ini metode analisis kuantitatif karena penelitian ini ditopang dengan data-data kuantitatif dalam laporan keuangan (neraca dan laporan laba-rugi) dan perhitungan-perhitungan terhadap data tersebut. Hasil penelitian menunjukkan bahwa selama 3 tahun yaitu tahun 2009 kondisi keuangan perusahaan cenderung kurang sehat walaupun tahun 2010 kondisi keuangannya lebih baik daripada tahun 2009. Kondisi kinerja keuangan perusahaan tahun 2009 memperoleh skor sebesar 35 yang mengindikasikan perusahaan Kurang Sehat dengan kategori B. Indikator paling dominan tahun 2009 adalah current ratio yaitu nilai current ratio sebesar $458,876 \%$ atau skor 3 . Tahun 2010 kondisi kinerja keuangan perusahaan lebih baik daripada tahun 2009 yaitu memperoleh skor sebesar 40,5 (naik 5,5 dibandingkan tahun 2009) yang mengindikasikan perusahaan Kurang Sehat dengan kategori BB. Indikator paling dominan pada tahun 2010 adalah current ratio yaitu nilai current ratio sebesar 488,812\% atau dengan skor 3. Tahun 2009 dan tahun 2010 PDAM Kabupaten Kupang tidak bisa mempertahankan kinerja keuangannya pada tahun 2011 yaitu kondisi keuangannya cenderung untuk turun dan mengindikasikan kondisi keuangan perusahaan dalam keadaan tidak baik. Pada tahun 2011 perusahaan memperoleh skor sebesar 28 yang mengindikasikan kondisi keuangan perusahaan Tidak Sehat dengan kategori CCC. Indikator paling dominan pada tahun 2012 adalah current ratio yaitu nilai current ratio sebesar 428,958\% atau skor sebesar 3.
\end{abstract}

Kata Kunci : Kinerja Keuangan Perusahaan.

*) Munawar ; Dosen Program Studi Akuntansi Sektor Publik Politeknik Negeri Kupang.

PENDAHULUAN

Perusahaan dengan kinerja yang

baik adalah perusahaan yang dapat memanfaatkan sumber-sumber daya yang tersedia dengan cara yang efektif dan efisien, dengan tujuan untuk dapat

\section{POLITEKNIK NEGERI KUPANG}


mencapai hasil yang optimal. Dampak dari efisiensi dan efektivitas yang dicapai tersebut ditandai dengan meningkatnya harga pasar saham milik perusahaan, atau dalam perusahaan perseorangan yaitu dengan meningkatnya laba pemilik perusahaan. Sumber daya keuangan yang tersedia di perusahaan terdari dari modal atau investasi yang ditanamkan oleh pemilik perusahaan. Modal atau investasi tersebut dipergunakan untuk membiayai operasionalisasi perusahaan. Hasil yang ingin dicapai oleh perusahaan adalah tingkat keuntungan atau laba yang optimal, serta meningkatnya kemakmuran pemilik perusahaan.

Salah satu alat penilaian kinerja suatu perusahaan adalah dengan menggunakan analisis rasio keuangan, yang dibuat berdasarkan laporan keuangan perusahaan pada suatu periode tertentu. Setiap organisasi bisnis melakukan transaksinya dalam satuan moneter, dan setiap transaksi yang dilakukan oleh perusahaan dalam operasinya harus dicatat. Catatan-catatan mengenai transaksi perusahaan terakumulasi dalam laporan keuangan yang dibuat oleh perusahaan setiap periode tertentu. Kekayaan dan hasil kinerja manajer dari hasil transaksi bisnis juga tergambar dalam laporan keuangan. Berdasarkan alasan di atas, sumber pengukuran atau evaluasi kinerja keuangan perusahaan terutama berasal dari laporan keuangan. Analisis keuangan melibatkan penilaian terhadap keadaan keuangan di masa lalu, sekarang, dan masa yang akan datang.

Tujuan analisis rasio keuangan dilakukan untuk menemukan kelemahankelemahan di dalam kinerja keuangan yang dapat menimbulkan masalahmasalah di masa yang akan datang, dan untuk menentukan kekuatan-kekuatan perusahaan yang dapat diandalkan. Analisis rasio menghubungkan unsurunsur dalam laporan keuangan satu dengan lainnya yang saling berkaitan, sehingga dapat memberikan gambaran mengenai posisi dan kondisi keuangan perusahaan pada suatu saat tertentu, serta dapat menilai efisiensi dan efektivitas pemanfaatan dana dalam operasional perusahaan. Rasio-rasio keuangan umumnya diklasifikasikan dalam empat jenis rasio, yaitu rasio likuiditas, rasio aktivitas, rasio leverage, rasio profitabilitas.

Perusahaan Daerah Air Minum (PDAM) Kabupaten Kupang merupakan perusahaan yang bergerak dalam usaha jasa pelayanan air bersih untuk masyarakat diwilayah Kota Kupang dan sekitarnya dan telah beroperasi dalam kurun waktu yang relatif lama di Kota Kupang. Keberadaan Perusahaan Daerah Air Minum (PDAM) ini sangat dibutuhkan oleh masyarakat Kota Kupang dan sekitarnya dalam kehidupan sehari-hari. Adanya persaingan dengan perusahaan yang sama diwilayah Kota Kupang, membuat Perusahaan Daerah Air Minum (PDAM) untuk terus bersiaga terhadap tekanan melonjaknya biaya dan adanya persaingan yang semakin ketat seiring dengan semakin besarnya kebutuhan masyarakat terhadap kebutuhan air bersih.

Persaingan yang semakin ketat,

\section{POLITEKNIK NEGERI KUPANG}


menyebabkan Perusahaan Daerah Air Minum (PDAM) berusaha untuk tetap bertahan (survive). Salah satu cara yang dapat dilakukan perusahaan adalah dengan melakukan analisis terhadap laporan keuangan yaitu menggunakan rasio keuangan, yang digunakan untuk mengetahui kinerja keuangan perusahaan. Setelah kinerja keuangan perusahaan diketahui, maka dapat dianalisis sehat atau tidaknya perusahaan terutama dalam hal keuangan, sehingga perusahaan dapat mengetahui resiko yang akan dihadapi oleh perusahaan Perusahaan Daerah Air Minum (PDAM) di masa yang akan datang.

Dari pertimbangan pentingnya analisis laporan keuangan dalam menilai kinerja keuangan perusahaan, maka penulis akan melakukan penelitian tentang "Analisis Kinerja Keuangan Perusahaan Pada Perusahaan Daerah Air Minum Kabupaten Kupang ".

\section{PERUMUSAN MASALAH}

Berdasarkan dari uraian di atas, penulis merumuskan permasalahan pada penelitian ini yaitu, "Bagaimana perbandingan rasio keuangan sebagai salah satu alat untuk menilai kinerja keuangan pada Perusahaan Daerah Air Minum Kabupaten Kupang?"

\section{TUJUAN PENELITIAN}

Secara umum tujuan dari penelitian ini adalah untuk mengetahui kinerja keuangan perusahaan dengan menggunakan alat analisis rasio keuangan peruahaan. Secara khusus tujuan dari penelitian ini adalah :

1. Mengetahui penggunaan rasio keuangan sebagai salah satu alat untuk menilai kinerja keuangan.

2. Mengetahui penerapan keputusan Menteri Keuangan tentang penilaian kinerja

\section{TINJAUAN PUSTAKA}

\section{Laporan Keuangan}

Laporan keuangan merupakan hasil akhir dari proses akuntansi yang dibuat oleh manajemen perusahaan untuk mempertanggungjawabkan semua operasi atau aktivitas perusahaan dalam suatu periode tertentu. Proses akuntansi tersebut meliputi aktivitas pencatatan, penggolongan dan peringkasan dari peristiwa dan kejadian yang bersifat keuangan dengan berlandaskan pada suatu prinsip-prinsip tertentu, yaitu prinsip akuntansi yang dapat diterima secara umum.

Pengertian tentang laporan keuangan perusahaan sudah banyak didefinisikan oleh pakar manajemen keuangan. Laporan keuangan adalah hasil akhir dari suatu proses akuntansi yang meliputi dua laporan utama yakni neraca dan laporan laba-rugi dengan maksud untuk menyediakan informasi keuangan suatu perusahaan kepada pihak-pihak yang berkepentingan sebagai bahan pertimbangan di dalam mengambil keputusan (Slamet, 2004:21). Pendapat senada yang 
mengungkapkan pengertian laporan keuangan adalah hasil dari proses akuntansi yang dapat digunakan sebagai alat untuk berkomunikasi antara data keuangan atau aktivitas suatu perusahaan dengan pihak-pihak yang berkepentingan dengan data atau aktivitas perusahaan tersebut (Munawir, 2001:2).

\section{Analisis Laporan Keuangan}

Analisis laporan keuangan adalah suatu alat yang dapat dipergunakan untuk membuat suatu keputusan antara lain mengenai rencana-rencana perluasan perusahaan, penanaman modal (investasi), pencarian sumber-sumber dana operasi perusahaan (Widjaja, 1995:22). Analisis laporan keuangan merupakan suatu proses yang penuh pertimbangan dalam rangka membantu mengevaluasi posisi keuangan dan hasil operasi perusahaan pada masa sekarang dan masa lalu, serta untuk menentukan estimasi dan prediksi yang paling mungkin mengenai kondisi dan kinerja perusahaan pada masa mendatang (Prastowo, 2002:52).

\section{Analisis Rasio Keuangan}

Rasio menggambarkan suatu hubungan atau pertimbangan (mathematical relationship) antara suatu jumlah tertentu dengan jumlah yang lain, dan dengan menggunakan alat analisis berupa rasio ini akan dapat menjelaskan atau memberikan gambaran kepada penganalisis mengenai baik atau buruknya keadaan atau kondisi keuangan suatu perusahaan (Munawir, 2001:64). Perbandingan analisis rasio keuangan meliputi dua jenis yaitu Analis dapat memperbandingkan rasio sekarang dengan yang lalu dan yang akan datang untuk perusahaan yang sama (perbandingan internal) dan perbandingan meliputi perbandingan rasio perusahaan dengan perusahaan lainnya yang sejenis atau dengan rata-rata industri pada satu titik yang sama (perbandingan eksternal) (Sawir, 2001:7).

Pendapat lain dalam melakukan analisis rasio keuangan adalah terdapat beberapa metode pembandingan yaitu cross sectional approach dan time series analysis (Syamsuddin, 1998:39).Cross sectional approach adalah cara mengevaluasi dengan jalan membandingkan rasio-rasio keuangan antara perusahaan yang satu dengan perusahaan lain yang sejenis pada saat bersamaan. Time series analysis adalah cara mengevaluasi dengan jalan membandingkan rasio-rasio keuangan perusahaan dalam satu periode dengan periode lainnya.

\section{Kinerja Perusahaan}

Kinerja adalah hasil dari banyak keputusan individual yang dibuat secara terus menerus oleh manajemen (Helfert, 1993:52). Selain itu juga kinerja erat hubungannya dengan efektifitas dan efisiensi penggunaan sumber daya yang dimiliki oleh perusahaan dalam mencapai tujuan yang telah ditetapkan sebelumnya. Efektifitas adalah pencapaian tujuan yang dikehendaki tanpa menghiraukan faktorfaktor tenaga, waktu, biaya, pikiran, alatalat dan lain-lain yang telah dikeluarkan, sedang fisiensi adalah perbandingan yang 
terbaik antara masukan (input) dan keluaran (output) atau antara daya dan hasil (Winarso, 1995:74).

Salah satu kriteria dalam penilaian kinerja suatu perusahaan adalah efektivitas dan efisiensi. Namun kriteria efektivitas dan efisiensi ini berbeda-beda antara organisasi yang satu dengan yang lainnya, hal ini disebabkan bahwa setiap organisasi mempunyai sifat, ukuran maupun struktur yang berbeda.

\section{METODE PENELITIAN}

Jenis dan Sumber Data

Sumber data dalam penelitian ini adalah data primer yaitu data yang diperoleh langsung dari sumbernya, yaitu laporan keuangan perusahaan PDAM Kabupaten Kupang yang telah dibuat. Pengumpulan data yang dilakukan dalam penelitian ini dilakukan dengan cara dokumentasi, yaitu merupakan teknik pengumpulan data dengan cara mengambil, melihat dan atau mengambil langsung dokumen-dokumen, arsip-arsip serta catatan-catatan lainnya. Dalam dokumentasi ini, penulis berusaha mendapatkan data yang berisi laporan keuangan perusahaan serta data-data lain yang tertuang dalam suatu dokumen dan berkaitan erat dengan topik penelitian yang diambil.

\section{Analisis Data}

Metode analisis yang digunakan dalam penelitian ini adalah metode analisis kuantitatif karena penelitian ini ditopang dengan data-data kuantitatif dalam laporan keuangan (neraca dan laporan laba-rugi) dan perhitungan-perhitungan terhadap data tersebut. Tahap-tahap analisis yang akan dilakukan adalah sebagai berikut:

a. Menganalisis kinerja keuangan perusahaan Perusahaan Daerah Air Minum Kabupaten Kupang berdasarkan rasio keuangan Times Series Analysis.

b. Menganalisis kinerja keuangan Perusahaan Daerah Air Minum Kabupaten Kupang berdasarkan rasio keuangan Cross Section Approach.

c. Penilaian kinerja keuangan Perusahaan Daerah Air Minum Kabupaten Kupang berdasarkan analisis perbandingan laporan keuangan dan analisis rasio keuangan.

Penilaian kinerja keuangan Perusahaan Daerah Air Minum Kabupaten Kupang berdasarkan Keputusan Menteri Keuangan Republik Indonesia Nomor: Kep-

100/MBU/2002.

Tabel 2.1 Indikator dan Nilai Kinerja (Kep100/MBU/2002)

\begin{tabular}{|c|c|c|}
\hline No & Indikator & Nilai \\
\hline 1 & Return On Equity & 15 \\
\hline 2 & Return On Investment & 10 \\
\hline 3 & Cash Ratio & 3 \\
\hline 4 & Current Ratio & 4 \\
\hline 5 & Collection Period & 4 \\
\hline 6 & Inventory Turnover & 4 \\
\hline 7 & Total Asset Turnover & 4 \\
\hline 8 & $\begin{array}{l}\text { Total Modal Sendiri terhadap Total } \\
\text { Aktiva }\end{array}$ & 6 \\
\hline \multicolumn{2}{|r|}{ Total Bobot } & 50 \\
\hline
\end{tabular}


Batasan indikator dan penilaian kinerja keuangan berdasarkan Keputusan Menteri Keuangan Nomor: Kep100/MBU/2002 adalah sebagai berikut:

a. Nilai Return On Equity

Tabel 2.2 Nilai Return On Equity (Kep100/MBU/2002)

\begin{tabular}{|lll|c|}
\hline \multicolumn{3}{|c|}{ Return On Equity (\%) } & Skor \\
\hline 15 & $<$ & Return On Equity & 15 \\
\hline 13 & $<$ & Return On Equity & 13,5 \\
\hline 11 & $<$ & Return On Equity & 12 \\
\hline 9 & $<$ & Return On Equity & 10,5 \\
\hline 7,9 & $<$ & Return On Equity & 9 \\
\hline 6,6 & $<$ & Return On Equity & 7,5 \\
\hline 5,3 & $<$ & Return On Equity & 6 \\
\hline 4 & $<$ & Return On Equity & 5 \\
\hline 2,5 & $<$ & Return On Equity & 4 \\
\hline 1 & $<$ & Return On Equity & 3 \\
\hline 0 & $<$ & Return On Equity & 1,5 \\
\hline & & Return On Equity & 1 \\
\hline & & & \\
\hline
\end{tabular}

b. $\quad$ Nilai Return On Investment

Tabel 2.3 Nilai Return On Investment (Kep100/MBU/2002

\begin{tabular}{|lll|c|}
\hline \multicolumn{3}{|c|}{ Return On Equity (\%) } & Skor \\
\hline 18 & $<$ & Return On Investment & 10 \\
\hline 15 & $<$ & Return On Investment & 9 \\
\hline 13 & $<$ & Return On Investment & 8 \\
\hline 12 & $<$ & Return On Investment & 7 \\
\hline 10,5 & $<$ & Return On Investment & 6 \\
\hline 9 & $<$ & Return On Investment & 5 \\
\hline 7 & $<$ & Return On Investment & 4 \\
\hline 5 & $<$ & Return On Investment & 3,5 \\
\hline 3 & $<$ & Return On Investment & 3 \\
\hline
\end{tabular}

\begin{tabular}{|ccc|c|}
\hline 1 & $<$ & Return On Investment & 2,5 \\
\hline 0 & $<$ & Return On Investment & 2 \\
\hline & & Return On Investment & 0 \\
\hline
\end{tabular}

c. Nilai Cash Ratio

Tabel 2.4 Nilai Cash Ratio (Kep-100/MBU/2002)

\begin{tabular}{|c|c|}
\hline Cash Ratio (\%) & Skor \\
\hline Cash Ratio $\geq 35$ & 3 \\
\hline $25 \leq$ Cash Ratio < 35 & 2,5 \\
\hline $15 \leq$ Cash Ratio < 25 & 2 \\
\hline $10 \leq$ Cash Ratio < $<15$ & 1,5 \\
\hline $5 \leq$ Cash Ratio < & 1 \\
\hline $0 \leq$ Cash Ratio < & 0 \\
\hline
\end{tabular}

d. Nilai Current Ratio

Tabel 2.5 Nilai Current Ratio (Kep-100/MBU/2002)

\begin{tabular}{|cccc|c|}
\hline \multicolumn{3}{|c|}{ Quick Ratio (\%) } & Skor \\
\hline 125 & $\leq$ & Current Ratio & & 3 \\
\hline 110 & $\leq$ & Current Ratio & $<$ & 2,5 \\
\hline 100 & $\leq$ & Current Ratio & $<$ & 2 \\
\hline 95 & $\leq$ & Current Ratio & $<$ & 1,5 \\
\hline 90 & $\leq$ & Current Ratio & $<$ & 1 \\
\hline & Current Ratio & $<$ & 0 \\
\hline
\end{tabular}

e.

Nilai Collection Period

Tabel 2.6 Nilai Collection Period (Kep-100/MBU/2002)

\begin{tabular}{|c|c|c|}
\hline $\begin{array}{c}\text { Collection Period }=\mathrm{X} \\
\text { (hari) }\end{array}$ & Perbaikan = X (hari) & Skor \\
\hline $\mathrm{X} \leq$ & $30<\mathrm{X} \leq$ & 4 \\
\hline $60<\mathrm{X} \leq$ & $25<\mathrm{X} \leq 30$ & 3 \\
\hline $90<\mathrm{X} \leq$ & $20<\mathrm{X} \leq 25$ & 2,5 \\
\hline $120<\mathrm{X} \leq$ & $15<\mathrm{X} \leq 20$ & 2 \\
\hline $150<\mathrm{X} \leq$ & $10<\mathrm{X} \leq 15$ & 1,6 \\
\hline $180<\mathrm{X} \leq$ &
\end{tabular}




\begin{tabular}{|c|c|c|}
\hline $210<X \leq$ & $6<X \leq 10$ & 1,2 \\
\hline $240<X \leq$ & $3<X \leq 6$ & 0,8 \\
\hline $270<X \leq$ & $1<X \leq 3$ & 0,4 \\
\hline $300<X$ & $0<X \leq 1$ & 0 \\
\hline
\end{tabular}

\begin{tabular}{|c|c|c|c|}
\hline $40<\mathrm{X}$ & $<60$ & $<\mathrm{X} \leq 15$ & 1,5 \\
\hline $20<\mathrm{X} \leq 40$ & $<\mathrm{X} \leq 10$ & 1 \\
\hline & $<\mathrm{X} \leq 20$ & $<\mathrm{X}$ & 0,5 \\
\hline
\end{tabular}

h. Nilai Total Modal Sendiri terhadap Total Aktiva

f. Nilai Inventory Turnover

Tabel 2.7 Nilai Inventory Turnover (Kep-100/MBU/2002)

\begin{tabular}{|c|c|c|}
\hline $\begin{array}{c}\text { Inventory Turnover }=\mathrm{X} \\
\text { (hari) }\end{array}$ & Perbaikan $=$ X $($ hari $)$ & Skor \\
\hline$X \leq 60$ & 35 & 4 \\
\hline $60<X \leq 90$ & $30<X \leq 35$ & 3,5 \\
\hline $90<\mathrm{X} \leq 120$ & $25<X \leq 30$ & 3 \\
\hline $120<\mathrm{X} \leq 150$ & $20<X \leq 25$ & 2,5 \\
\hline $150<\mathrm{X} \leq 180$ & $15<X \leq 20$ & 2 \\
\hline $180<X \leq 210$ & $10<X \leq 15$ & 1,6 \\
\hline $210<X \leq 240$ & $<X \leq 10$ & 1,2 \\
\hline $240<X \leq 270$ & $<X \leq 6$ & 0,8 \\
\hline $270<X \leq 300$ & $1<X \leq 3$ & 0,4 \\
\hline $300<\mathrm{X}$ & $0<X \leq 1$ & 0 \\
\hline
\end{tabular}

g. Nilai Total Asset Turnover

Tabel 2.8 Nilai Total Asset Turnover (Kep-100/MBU/2002)

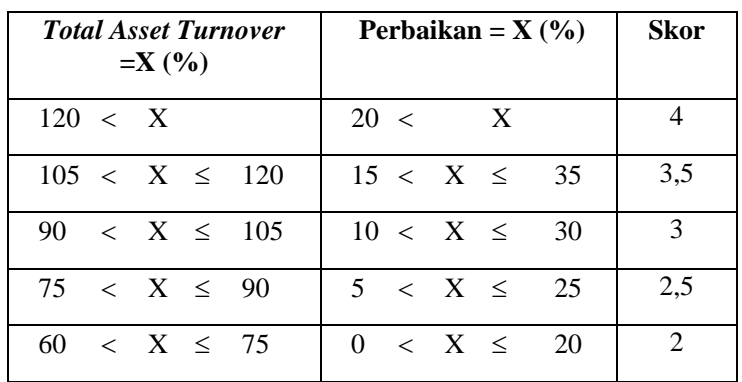

Tabel 2.9 Total Modal Sendiri terhadap

Total Aktiva

(Kep.100/MBU/2002)

\begin{tabular}{|c|c|c|}
\hline \multicolumn{2}{|c|}{ Total Modal Sendiri terhadap Total Aktiva (\%) } & \multirow{2}{*}{$\begin{array}{c}\text { Sko } \\
\text { r } \\
0\end{array}$} \\
\hline Aktiva $<$ & $\begin{array}{l}\text { Total Modal Sendiri terhadap Total } \\
0\end{array}$ & \\
\hline $\begin{array}{l}0 \leq \\
\text { Aktiva }<\end{array}$ & $\begin{array}{l}\text { Total Modal Sendiri terhadap Total } \\
10\end{array}$ & 2 \\
\hline $\begin{array}{l}10 \leq \\
\text { Aktiva }<\end{array}$ & $\begin{array}{l}\text { Total Modal Sendiri terhadap Total } \\
20\end{array}$ & 3 \\
\hline $\begin{array}{l}20 \leq \\
\text { Aktiva }<\end{array}$ & $\begin{array}{l}\text { Total Modal Sendiri terhadap Total } \\
30\end{array}$ & 4 \\
\hline $\begin{array}{l}30 \leq \\
\text { Aktiva }<\end{array}$ & $\begin{array}{l}\text { Total Modal Sendiri terhadap Total } \\
40\end{array}$ & 6 \\
\hline $\begin{array}{l}40 \leq \\
\text { Aktiva }<\end{array}$ & $\begin{array}{l}\text { Total Modal Sendiri terhadap Total } \\
50\end{array}$ & 5,5 \\
\hline $\begin{array}{l}50 \leq \\
\text { Aktiva }<\end{array}$ & $\begin{array}{l}\text { Total Modal Sendiri terhadap Total } \\
60\end{array}$ & 5 \\
\hline $\begin{array}{l}60 \leq \\
\text { Aktiva }<\end{array}$ & $\begin{array}{l}\text { Total Modal Sendiri terhadap Total } \\
70\end{array}$ & 4,5 \\
\hline $\begin{array}{l}70 \leq \\
\text { Aktiva }<\end{array}$ & $\begin{array}{l}\text { Total Modal Sendiri terhadap Total } \\
80\end{array}$ & 4,25 \\
\hline $\begin{array}{l}80 \leq \\
\text { Aktiva }<\end{array}$ & $\begin{array}{l}\text { Total Modal Sendiri terhadap Total } \\
90\end{array}$ & 4 \\
\hline $\begin{array}{l}90 \leq \\
\text { Aktiva }<\end{array}$ & $\begin{array}{l}\text { Total Modal Sendiri terhadap Total } \\
100\end{array}$ & 3,5 \\
\hline
\end{tabular}

Untuk menilai kinerja keuangan perusahaan berdasarkan Keputusan Menteri Keuangan Nomor: Kep100/MBU/2002 menggunakan langkah :

a. Menentukan nilai kinerja keuangan yaitu dengan menjumlahkan nilai

\section{POLITEKNIK NEGERI KUPANG}

| ISSN 2528-0651 
setiap indikator yaitu nilai return on equity, nilai return on investment, nilai cash ratio, nilai current ratio, nilai collection period, nilai inventory turnover, nilai total asset turnover, dan nilai net working capital to total asset.

b. Mengklasifikasikan kinerja keuangan berdasarkan Keputusan Menteri Keuangan Nomor: Kep100/MBU/2002 adalah sebagai berikut:

1 SEHAT, yang terdiri dari:

AAA : apabila nilai yang dicapai lebih besar dari 95

AA : apabila nilai yang dicapai lebih besar dari $80 \mathrm{~s} / \mathrm{d} 95$

A : apabila nilai yang dicapai lebih besar dari 65 s/d 80

2 KURANG SEHAT, yang terdiri dari:

BBB : apabila nilai yang dicapai lebih besar dari $50 \mathrm{~s} / \mathrm{d} 65$
BB : apabila nilai yang dicapai lebih besar dari 40 s/d 50

B : apabila nilai yang dicapai lebih besar dari 30 s/d 40

3 TIDAK SEHAT, yang terdiri dari:

CCC : apabila nilai yang dicapai lebih besar dari $20 \mathrm{~s} / \mathrm{d} 30$

CC : apabila nilai yang dicapai lebih besar dari 10 s/d 20

C : apabila nilai yang dicapai 10 ke bawah.

\section{HASIL PENELITIAN}

Analisis dan Intepretasi

Penghitungan Kinerja Keuangan

PDAM Kabupaten Kupang

(Berdasarkan Keputusan Menteri

Keuangan Nomor: Kep100/MBU/2002)

Tabel : 1

\begin{tabular}{|c|c|c|c|c|}
\hline Rasio & Nilai & \multicolumn{2}{|c|}{ Klasifikasi Nilai } & Skor \\
\hline \multicolumn{5}{|l|}{ Tahun 2009} \\
\hline Return On Equity & 13,809 & \multicolumn{2}{|l|}{$13<\mathrm{ROE} \leq 15$} & 13,5 \\
\hline Return On Investment & 11,303 & \multicolumn{2}{|l|}{$10,5<\mathrm{ROI} \leq 12$} & 6 \\
\hline Cash Ratio & 277,022 & \multicolumn{2}{|l|}{$\mathrm{CaR} \geq 35$} & 3 \\
\hline Current Ratio & 458,876 & \multicolumn{2}{|l|}{$125 \leq \mathrm{CR}$} & 3 \\
\hline Collection Period & 77 & $60<\mathrm{CP} \leq 90$ & 3,5 & \multirow[b]{2}{*}{3,5} \\
\hline Perbaikan Collection Period & - & - & - & \\
\hline Inventory Turnover & 420 & $300<$ ITO & 0 & \multirow[b]{2}{*}{0} \\
\hline Perbaikan Inventory Turnover & - & - & - & \\
\hline Total Asset Turnover & 69,800 & $60<$ TATO $\leq$ & 2 & 2 \\
\hline
\end{tabular}




\begin{tabular}{|c|c|c|c|c|}
\hline & & 75 & & \\
\hline Perbaikan Total Asset Turnover & - & - & - & \\
\hline $\begin{array}{l}\text { Total Modal Sendiri terhadap Total } \\
\text { Aset }\end{array}$ & 81,852 & $\begin{array}{l}80<\text { TMS Thd } \\
90\end{array}$ & $\mathrm{TA} \leq$ & 4 \\
\hline \multicolumn{4}{|l|}{ Total Skor } & 35 \\
\hline \multicolumn{5}{|l|}{ Tahun 2010} \\
\hline Return On Equity & 14,601 & \multicolumn{2}{|l|}{$13<\mathrm{ROE} \leq 15$} & 13,5 \\
\hline Return On Investment & 12,326 & \multicolumn{2}{|l|}{$12<\mathrm{ROI} \leq 13$} & 7 \\
\hline Cash Ratio & 263,472 & \multicolumn{2}{|l|}{$\mathrm{CaR} \geq 35$} & 3 \\
\hline Current Ratio & 488,812 & \multicolumn{2}{|l|}{$125 \leq \mathrm{CR}$} & 3 \\
\hline Collection Period & 73 & $60<\mathrm{CP} \leq 90$ & 3,5 & \multirow[b]{2}{*}{3,5} \\
\hline Perbaikan Collection Period & 4 & $0<\mathrm{CP} \leq 1$ & 0 & \\
\hline Inventory Turnover & 461 & $300<$ ITO & 0 & \multirow[b]{2}{*}{4} \\
\hline Perbaikan Inventory Turnover & 41 & ITO $\leq 35$ & 4 & \\
\hline Total Asset Turnover & 77,400 & $\begin{array}{l}75<\text { TATO } \leq \\
90\end{array}$ & 2,5 & \multirow[t]{2}{*}{2,5} \\
\hline Perbaikan Total Asset Turnover & 7,600 & $0<\mathrm{TATO} \leq 20$ & 2 & \\
\hline $\begin{array}{l}\text { Total Modal Sendiri terhadap Total } \\
\text { Aset }\end{array}$ & 84,415 & \multicolumn{2}{|c|}{$80<\mathrm{TMS}$ to $\mathrm{TA} \leq 90$} & 4 \\
\hline \multicolumn{4}{|l|}{ Total Skor } & 40,5 \\
\hline \multicolumn{5}{|l|}{ Tahun 2012} \\
\hline Return On Equity & 8,516 & \multicolumn{2}{|l|}{$7,9<\mathrm{ROE} \leq 9$} & 9 \\
\hline Return On Investment & 7,015 & \multicolumn{2}{|l|}{$7<\mathrm{ROI} \leq 9$} & 4 \\
\hline Cash Ratio & 141,667 & \multicolumn{2}{|l|}{$\mathrm{CaR} \geq 35$} & 3 \\
\hline Current Ratio & 428,958 & \multicolumn{2}{|l|}{$125 \leq \mathrm{CR}$} & 3 \\
\hline Collection Period & 93 & $90<\mathrm{CP} \leq 120$ & 3 & \multirow[b]{2}{*}{2,5} \\
\hline Perbaikan Collection Period & -20 & $20<\mathrm{CP} \leq 25$ & 2,5 & \\
\hline Inventory Turnover & 462 & $300<$ ITO & 0 & \multirow{2}{*}{0} \\
\hline Perbaikan Inventory Turnover & 1 & $0<\mathrm{ITO} \leq 1$ & 0 & \\
\hline Total Asset Turnover & 86,800 & $\begin{array}{l}75<\text { TATO } \leq \\
90\end{array}$ & 2,5 & \multirow[t]{2}{*}{2,5} \\
\hline Perbaikan Total Asset Turnover & 9,400 & $0<\mathrm{TATO} \leq 20$ & 2 & \\
\hline $\begin{array}{l}\text { Total Modal Sendiri terhadap Total } \\
\text { Aset }\end{array}$ & 82,374 & \multicolumn{2}{|c|}{$80<$ TMS to $\mathrm{TA} \leq 90$} & 4 \\
\hline \multicolumn{4}{|l|}{ Total Skor } & 28 \\
\hline
\end{tabular}


Penilaian kinerja keuangan (Berdasarkan Keputusan Menteri perusahaan berdasarkan Keputusan Keuangan Komor: KepMenteri Keuangan Nomor: Kep- 100/MBU/2002) dapat diketahui 100/MBU/2002 terlebih dahulu penggolongan kinerja keuangan menentukan nilai kinerja keuangan yaitu perusahaan selama tahun 2009 sampai dengan menjumlahkan nilai setiap tahun 2011 dapat dilihat pada tabel indikator. Setelah itu mengklasifikasikan kinerja keuangan berdasarkan Keputusan Menteri Keuangan Nomor: Kep100/MBU/2002. dibawah ini.

Tabel 2. Penilaian Kinerja Keuangan PDAM Kabupaten Kupang (Berdasarkan Keputusan

Berdasarkan hasil Penghitungan Kinerja Keuangan PDAM Kabupaten Kupang

\begin{tabular}{|c|l|c|c|c|}
\hline No & \multicolumn{1}{|c|}{ Nama Perusahaan } & \multirow{2}{*}{$\begin{array}{c}\text { Jumlah } \\
\text { Skor }\end{array}$} & \multicolumn{2}{|c|}{ Penilaian Kinerja } \\
\cline { 4 - 5 } & & & & Tingkat Kinerja \\
\hline 1 & PDAM Kabupaten Kupang & & & \\
\hline & a. Tahun 2009 & 35 & Kurang Sehat & B \\
\hline & b. Tahun 2010 & 40,5 & Kurang Sehat & BB \\
\hline & c. Tahun 2011 & 28 & Tidak Sehat & CCC \\
\hline
\end{tabular}

Sumber : data diolah Menteri Keuangan Nomor : Kep-100/MBU/2002)

Berdasarkan tabel di atas memperlihatkan hasil penilaian kinerja perusahaan berdasarkan Keputusan Menteri Keuangan Nomor : Kep100/MBU/2002, yaitu :

Selama 3 tahun yaitu pada tahun 2009 kondisi keuangan perusahaan cenderung kurang sehat walaupun tahun 2010 kondisi keuangannya lebih baik daripada tahun 2009. Kondisi kinerja keuangan perusahaan tahun 2009 memperoleh skor sebesar 35 yang mengindikasikan perusahaan Kurang Sehat dengan kategori B. Indikator paling dominan tahun 2009 adalah current ratio yaitu nilai current ratio sebesar $458,876 \%$ atau skor 3 .

Tahun 2010 kondisi kinerja keuangan perusahaan lebih baik daripada tahun 2009 yaitu memperoleh skor sebesar 40,5 (naik 5,5 dibandingkan tahun 2009) yang mengindikasikan perusahaan Kurang Sehat dengan kategori BB. Indikator paling dominan pada tahun 2010 adalah current ratio yaitu nilai current ratio sebesar $488,812 \%$ atau dengan skor 3. Tahun 2009 dan tahun 2010 PDAM Kabupaten Kupang tidak bisa mempertahankan kinerja keuangannya pada tahun 2011 yaitu kondisi keuangannya cenderung untuk

\section{POLITEKNIK NEGERI KUPANG}


turun dan mengindikasikan kondisi keuangan perusahaan dalam keadaan tidak baik. Pada tahun 2011 perusahaan memperoleh skor sebesar 28 yang mengindikasikan kondisi keuangan perusahaan Tidak Sehat dengan kategori CCC. Indikator paling dominan pada tahun 2012 adalah current ratio yaitu nilai current ratio sebesar 428,958\% atau skor sebesar 3.

\section{PENUTUP}

\section{Kesimpulan:}

1. Selama 3 tahun yaitu tahun 2009 kondisi keuangan perusahaan cenderung kurang sehat walaupun tahun 2010 kondisi keuangannya lebih baik daripada tahun 2009. Kondisi kinerja keuangan perusahaan tahun 2009 memperoleh skor sebesar 35 yang mengindikasikan perusahaan Kurang Sehat dengan kategori B. Indikator paling dominan tahun 2009 adalah current ratio yaitu nilai current ratio sebesar $458,876 \%$ atau skor 3.

2. Tahun 2010 kondisi kinerja keuangan perusahaan lebih baik daripada tahun 2009 yaitu memperoleh skor sebesar 40,5 (naik 5,5 dibandingkan tahun 2009) yang mengindikasikan perusahaan Kurang Sehat dengan kategori BB. Indikator paling dominan pada tahun 2010 adalah current ratio yaitu nilai current ratio sebesar 488,812\% atau dengan skor 3 .

3. Tahun 2009 dan tahun 2010 PDAM Kabupaten Kupang tidak bisa mempertahankan kinerja

keuangannya pada tahun 2011 yaitu kondisi keuangannya cenderung untuk turun dan mengindikasikan kondisi keuangan perusahaan dalam keadaan tidak baik. Pada tahun 2011 perusahaan memperoleh skor sebesar 28 yang mengindikasikan kondisi keuangan perusahaan Tidak Sehat dengan kategori CCC. Indikator paling dominan pada tahun 2012 adalah current ratio yaitu nilai current ratio sebesar $428,958 \%$ atau skor sebesar 3.

\section{Implikasi}

Dari hasil penelitian ini mempunyai implikasi sebagai berikut :

a. Kondisi over likuid akan menyebabkan terjadinya aktiva lancar yang menganggur untuk itu manajemen perusahaan dapat mengalokasikan kelebihan modal kerja pada aktiva yang produktif.

b. Rendahnya nilai rasio likuiditas dan rasio profitabilitas perusahaan sebaiknya manajemen perusahaan mengalokasikan utang perusahaan untuk investasi aktiva tetap dengan harapan akan meningkatkan penjualan dan pendapatan (laba bersih) perusahaan.

c. Kondisi keuangan perusahaan dapat ditingkatkan dengan meningkatkan pengelolaan piutang perusahaan dengan meningkatkan perputaran piutang perusahaan dan mempercepat penagihan piutang perusahaan.

\section{POLITEKNIK NEGERI KUPANG}

| ISSN 2528-0651 


\section{DAFTAR PUSTAKA}

Arikunto, Suharsimi. 1998. Prosedur Penelitian (Suatu Pendekatan Praktek). Edisi Revisi IV. Jakarta: PT Rineka Cipta

Baridwan, Zaki. 2004. Intermediate Accounting. Edisi 7. Yogyakarta: BPFE Helfert, Erich. A. 1993. Analisis Laporan Keuangan. Edisi Ketujuh. Jakarta: Erlangga

Ikatan Akuntansi Indonesia. 2010. Standar Akuntansi Keuangan. Jakarta: Salemba Empat

Indriantoro, Nur., Supomo, Bambang., 2002. Metodologi Penelitian Bisnis (Untuk Akuntansi \& Manajemen). Yogyakarta: BPFE

Munawir, S. 2001. Analisa Laporan Keuangan. Edisi Keempat. Yogyakarta: Liberty

Nazir, M. 1999. Metode Penelitian. Cetakan Keempat. Jakarta: Ghalia Indonesia

Prastowo, D. Dwi. dan Juliaty, Rifka. 2002. Analisis Laporan Keuangan: (Konsep dan Aplikasi). Edisi
Revisi. Yogyakarta: UPP AMP YKPN

Riyanto, Bambang. 1995. Dasar-dasar Pembelanjaan Perusahaan. Edisi Kedua. Yogyakarta: Yayasan Badan Penerbit Gadjah Mada

Sawir, Agnes. 2001. Analisis Kinerja Keuangan dan Perencanaan Keuangan Perusahaan. Jakarta: PT. Gramedia Pustaka Utama

Slamet Sugiri, Bagat A. Riyono. 2004. Akuntansi Pengantar 1. Edisi kelima. Yogyakarta: AMP YKPN

Syamsuddin, Lukman. 1998. Manajemen Keuangan Perusahaan. Jakarta: PT. Raja Grafindo Persada

Weston, J. Fred \& Copeland, Thomas. E. Manajemen Keuangan. Edisi Kedelapan. Jakarta: Erlangga

Widjaja Tunggal, Amin. 1995. Dasardasar Analisis Laporan Keuangan. Jakarta: PT. Rineka Cipta

Winarso, Djoko. 1995. Organisasi \& Bisnis. Malang: Penerbit IKIP Malang. 